\title{
3 O Satanismo Metodológico: pode um saber compreensivo deixar de se compreender?
}

\section{Pedro Martins de Menezes ${ }^{1}$}

1 Bacharel em sociologia pela Universidade de Brasília (UnB), mestrando em sociologia pela mesma instituição e membro do grupo de pesquisa Cultura, Memória e Desenvolvimento (CMD).
RESUMO $O$ artigo versa sobre duas maneiras de se conduzir o exercício sociológico: uma em que a sociologia toma o mundo real como pressuposto e intenta se debruçar sobre ele para reproduzir seus sentidos de forma mimética e outra em que a disciplina objetiva se voltar sobre si mesma, abdicando de espelhar sentidos que lhe são exteriores para que instaure os seus próprios. No primeiro caso há uma trajetória retilínea de reprodução (Mimesis), no outro, uma metalinguagem obliqua de criação (Poiesis). Esse texto objetiva mostrar as implicações dessa escolha por parte do pesquisador, interrogando se um saber autorreflexivo pode deixar de se refletir.

Palavras-chave Mimesis; Poiesis; Verdade; Linguagem; Compreensão.
ABSTRACT This article deals with two manners of conducting the sociological practice: one in which sociology takes the real world as presupposed and intends to look at it in order to reproduce its significations in a mimetic way. Another in which the discipline intends to deal with itself by refusing to mirror the external significations in order to establish its own. In the first case, there is a rectilinear trajectory of reproduction (Mimesis), in the latter, an oblique metalanguage of creation (Poiesis).This text intends to show the implications of this choice by asking if a self-reflexive knowledge can stop reflecting itself.

KEYworDs Mimesis; Poiesis; Truth; Language; Comprehension. 
"Sabidamente não há classificação do universo que não seja arbitrária e conjectural. A razão é muito simples: não sabemos o que é o universo". Jorge Luis Borges. Outras Inquisições, 1952.

\section{Introdução}

Sabe-se que o ofício sociológico se presta a historicizar verdades, ou seja, a fazer com que estas deixem de ser tais a nossos olhos para que se reconheçam enquanto crenças. Depois que a sociologia debruça seus esforços sobre os objetos elencados, tudo aquilo que parecia eterno, natural e perenemente obrigatório se revela contextualizado, historicamente construído e facilmente cambiável. As verdades absolutas abandonam sua antiga autonomia para agora serem vistas como crenças apenas experimentadas como verdadeiras. Se antes os objetos eram concretos por eles mesmos, depois do esforço de pesquisa sociológico, a materialidade desses objetos abdica de ser uma potencialidade inerente a eles para que se descubra agora como uma qualidade construída histórica e compreensivamente por aqueles que experimentam tais artefatos. Mas, como uma ciência que reduz verdades a crenças (historicizando-as) enuncia suas próprias verdades? De que maneira lida com a naturalização um saber que se presta a transformar natureza em experiência? Ou, dito de outra maneira, é permitido que um ofício que intenta contextualizar os fenômenos se perenize? O que pode instaurar uma disciplina que é por natureza desconstrutivista?

São essas dificuldades próprias a um saber autorreflexivo, ou seja, que se questiona a todo momento em que questiona algo, fazendo com que os comentários tecidos sobre outros tópicos não deixem nunca de ser comentários sobre a essência do discurso comentador. Para que esse arranjo metalinguístico seja mantido faz-se necessário situar-se no próprio quadro analítico para que não se incorra na incoerência interna de construir um argumento que paire acima de si próprio, e que dessa forma se desminta. Ou seja, é fundamental que o recorte sobre o qual está se versando e o texto que discorre sobre esse objeto apresentem certa relação de parentesco, uma vez que tal discurso, ao falar do universo, passa a ser parte constitutiva dele. Esse trabalho, além de ser de muito elaborada execução, pode evidenciar lacunas na ideia proposta que permaneceriam turvas se o pesquisador não se esforçasse por olhar o modelo pelo prisma dele próprio. A tarefa de se 
1 “A partir do momento em que observamos o mundo social, introduzimos em nossa percepção um viés que se deve ao fato de que, para falar do mundo social, para estuda-lo a fim de falar sobre ele, etc., é preciso se retirar dele. $\mathrm{O}$ que se pode chamar de viés teoricista ou intelectualista consiste em esquecer de inscrever, na teoria que se faz do mundo social, o fato de ela ser produto de um olhar teórico. Para fazer uma ciência adequada do mundo social é preciso, ao mesmo tempo, produzir uma teoria (construir modelos, etc.) e introduzir na teoria final uma teoria da distância entre a teoria e a prática." (BOURDIEU, 1990: 115). posicionar dentro do esquema que se propõe, ou de aplicar o esquema a ele mesmo, não se reconhece aqui como um simples esforço de autocrítica ou um humilde ato de modéstia intelectual; muito pelo contrário: objetivar o discurso objetivante - para usarmos o famoso arranjo bourdiesiano ${ }^{1}$ - é uma prática que obriga o cientista social a revelar o percurso de construção de seu quadro de análise, fazendo com que sua obra seja a um só tempo a trajetória da elaboração de seu modelo e este próprio já terminado. Tal empresa intelectual se faz indispensável para que o legado do autor não se resuma a um punhado de enunciados de falso impacto intelectual e que se reconheça enquanto um modelo paradigmático de fato, uma esfera coerente e sem porosidades.

Mas, para além da dificuldade de se fechar esse arco intelectual e do fato de que esse trabalho possa vir a evidenciar as nebulosidades de nosso esquema de análise, um novo complicador vem se assomar a esses. Quando se esforça para montar um modelo coerente de estudo (que se pense ao pensar seus objetos), o sociólogo abdica de ser um legislador do mundo social para se reconhecer como um compositor de molduras intelectuais. Aquilo que poderia ser a profecia eterna e absoluta dos novos tempos ou do mundo tal qual o conhecemos se transforma em um simples argumento autocontido, contextualizado e limitado por duras arestas que ele mesmo erigiu para si. Esse deslocamento do discurso (que se queria o entendimento universal das coisas para se transformar num metatexto que só se entende a luz de si mesmo) inquieta muitos pesquisadores das ciências sociais que, a partir desse incômodo, passam ao largo da natureza metalinguística e autorreflexiva da sociologia para poder saciar sua vontade de ser, mais que porta-vozes da atualidade, a própria voz do presente; ou, para usarmos a díade que Bauman nos ensinou, recobrando sua posição de legisladores ao renunciarem ao ofício de intérpretes.

"A estratégia moderna do trabalho intelectual é aquela mais bem-caracterizada pela metáfora do papel do 'legislador'. Consiste em fazer afirmações autorizadas e autoritárias que arbitrem controvérsias de opiniões e escolham aquelas que, uma vez selecionadas, se tornem corretas e associativas. A autoridade para arbitrar é, nesse caso, legitimada por conhecimento (objetivo) superior, ao qual intelectuais têm mais acesso que a parte não intelectual da sociedade. Esse acesso se dá graças a regras 
de procedimento, garantindo que se alcance a verdade, que se chegue a um juízo moral válido e se selecione um gosto artístico apropriado. (...) [Já o papel do intérprete é aquele que] Consiste em traduzir afirmações feitas no interior de uma tradição baseada em termos comunais, a fim de que sejam compreendidas no interior de um sistema de conhecimento fundamentado em outra tradição. Em vez de orientar-se para selecionar a melhor ordem social, essa estratégia objetiva facilitar a comunicação entre participantes autônomos (soberanos). Preocupa-se em impedir distorções de significado no processo de comunicação. Para este fim, promove a necessidade de penetrar em profundidade o sistema estrangeiro de conhecimento do qual a tradução deve ser feita (por exemplo, a 'descrição densa' de Geertz) e a necessidade de manter o delicado equilíbrio entre as duas tradições que interagem, indispensável tanto para a mensagem não ser distorcida (com relação ao significado investido pelo remetente) quanto para ela ser compreendida (pelo destinatário).”

(BAUMAN, 2010: 19-21).
Por ter uma natureza autorreflexiva e compreensiva, a sociologia parece por vezes muito autocontida. Devido a essa ênfase metadiscursiva, parece que as ciências sociais dialogam apenas com elas mesmas sem nunca tecer enunciados sobre o "mundo lá fora". Essa constante conversa consigo mesmo ou com a constituição da disciplina que jamais transborda suas fronteiras passa a inquietar o cientista que, dessa maneira, se inclina a abdicar dessa essência metanarrativa e autorreflexiva para de fato passar a positivar o mundo e não apenas contextualizar as experiências compreensivas que o constituem. Mas será que podemos mesmo abrir mão de nossa alma autorreflexiva? Será possível passar ao largo do construtivismo compreensivo em nome do positivismo realista? Esse ensaio se presta a versar sobre essa opção (que a meu ver é a um só tempo moral e intelectual) de se produzir uma sociologia pela metade acreditando que se está erigindo uma em dobro. Para tal, elencou-se aqui, a título de metáfora, a imagem (já há muito presente nas artes) da venda da alma para o diabo. Seja na literatura ou no cinema, o demônio sempre faz suas propostas para aqueles corações insaciáveis que, na busca de satisfazerem suas vontades, já não podem mais contar com os esforços mundanos e terrenos, tendo 
2 Respectivamente os anti-heróis das obras literárias Fausto de Goethe, Dr. Fausto de Thomas Mann e do filme O Advogado do Diabo de Taylor Hackford. de recorrer às poderosas forças do inferno. Porém, o desenlace das trajetórias seja de Fausto, Adrian ou Keanu Reeves ${ }^{2}$ é sempre o mesmo: dar a alma em troca de nada quando se acreditava estar alcançando a satisfação plena; escolher uma vida finita de falso deleite em nome de uma eterna de verdadeiro sofrimento. Transportando a imagem para dentro do nosso problema, o que se intenta aqui é evidenciar as consequências (geralmente advindas de uma preguiça travestida de insaciabilidade) de se fazer uma sociologia que desiste de se debruçar sobre si própria ao acreditar que deita seus enunciados sobre o mundo real, abraçando uma falsa natureza realista em detrimento de uma verdadeiramente compreensiva. Resgatando o título do trabalho, o que se almeja aqui é dar conta da interrogação que atravessa todo esse texto: é possível um saber compreensivo deixar de se compreender?

\section{O satanismo metodológico}

Um binômio muito antigo atravessa e constitui o ofício do sociólogo. Essa díade, que parece ter a idade da própria disciplina, está presente em maior ou menor escala no texto e no estilo de muitos pesquisadores de nossa área. Falo aqui do binarismo "teoria/empírico". Desde muito tempo, essas duas semânticas são experimentadas pelo profissional de ciências sociais não como meros nomes - palavras inseparáveis e complementares ao mesmo tempo em que opostas - mas sim como verdadeiras substâncias investidas de concretude e de realidade. A partir dessa crença (que é vivenciada no ofício de pesquisa não como tal, mas como a própria verdade dos fatos) foram-se desenvolvendo pesquisas fundamentalmente teóricas e outras basicamente empíricas; da mesma forma, perguntas como "de qual teoria você lança mão nesse trabalho?” ou "qual o seu campo?” invadem os diálogos dos cientistas sociais, mesmo (ou talvez de maneira mais acentuada) em seu universo discente. Este modo de ver as coisas, que a primeira vista se nos apresenta como uma dimensão tão organizada e portanto bem vinda da natureza da disciplina, traz em seu bojo a marca da arbitrariedade uma vez que mutila o ofício de pesquisa - e o próprio pesquisador - em duas metades, dois instantes eternamente apartados e que dialogam apenas para que se ratifique sua complementaridade - o que é o mesmo que reconhecer o imperativo da impossibilidade de sua união. Teoria e empírico viram dois mundos separados por um fosso intransponível, dois momentos da atividade de pesquisa eternamente cindidos por uma fissura me- 
todológica que ao mesmo tempo em que os afasta um do outro, ratifica a assimetria de seus conteúdos.

Entre esses dois reinos tão distantes, opostos e de naturezas tão diferentes, está o sociólogo: este cientista - que também se acha repartido em dois (o empirista e o teorético) - ambicionando o status de bom pesquisador, carrega o fardo de passar a vida a ziguezaguear entre esses dois universos tão apartados. A figura que se forma em nossa imaginação é a de um homem que corre pelo vácuo separador dessas duas esferas do ofício sociológico em direção ao calor reconfortante da empiria para lá colher os dados de seu trabalho até que a temperatura se faz tão insuportável que ele se vê obrigado a abandonar esse reino e partir em disparada rumo à frieza dos clássicos. Neste outro polo da nossa profissão, o pobre diabo que é o sociólogo passa as páginas dos textos canônicos até que a ponta de seus dedos começa a congelar, só lhe restando como alternativa correr para as labaredas da empiria... E assim infinitamente, até que a pesquisa termine e numa nova se inicie.

Porém, se nas narrativas acerca do inferno os homens vendem a alma intentando gozar os prazeres de uma vida finita para no futuro penarem eternamente em outra dimensão, o satanismo da sociologia é diferente; neste reino, agonia e êxtase andam sempre juntos: se por um lado o ofício do sociólogo é esse eterno e infernal ir e vir, por outro lado - e ao mesmo tempo - o pesquisador se apresenta como o nomeador universal, verdadeiro Adão do submundo que colhe direto da fonte toda a concretude da empiria e encontra seu par na veracidade dos textos que só ele sabe ler. Se empírico e teórico são duas esferas investidas de matéria e realidade, bem como eternas e portanto anteriores ao próprio sociólogo, este se apresenta como o legítimo mensageiro da verdade: aquele que mostra ao mundo laico toda a realidade das coisas uma vez que, por ser dotado de um poder que ninguém mais tem, passa a ser o único capaz de relacionar nome e objeto. É por ter aceito em vida o calvário de ter que eternamente oscilar entre o calor da empiria e a frieza do teórico, que o sociólogo se configura como o porta-voz da concretude da vida, aquele que domina a verdade do mundo em suas mais diversas apresentações, sempre trazendo a única e derradeira versão dos fatos ou estes próprios em sua total nudez, como um verdadeiro Hermes do apocalipse. Nessa visão diabólica de ciências sociais, empiria e teoria se dispõem como duas paralelas infinitas e eternas cruzadas por um sociólogo que se esforça por encontrar no mundo concreto um correlato teórico, como um 
verdadeiro carimbador da vida. Se no satanismo metodológico, teoria e mundo de fato existem, cabe ao sociólogo, e só a ele, apresentá-los fielmente.

Sendo assim, o marco teórico de que lança mão não é apenas o texto que instrumentaliza, mas os próprios autores falando através da esfera de sua caneta; da mesma forma, o empírico que arregimenta, muito mais do que o seu campo, é o próprio mundo real que se inscreve nas páginas de seu artigo: a soberba e a vaidade sublinham os esforços desse homem. O intelectual vira um homem eterno que rasga com o absolutismo de seu discurso as fronteiras linguísticas de cada redoma simbólica. Por ser um nomeador geral e não pertencer a nenhum contexto, o cientista pode entrar em todos: um homem que, por ser desterritorializado, pode fazer de cada território o seu próprio. A grande vantagem de ser o indivíduo absoluto não é a de não ser nenhum indivíduo contextualizado, mas a de poder ser todos eles ao mesmo tempo:

"Como o conhecimento que produzem, os intelectuais não são restringidos por tradições localizadas, extraterritoriais, o que lhes dá o direito e o dever de validar (ou invalidar) crenças que possam ser sustentadas em vários seg- mentos da sociedade." (BAUMAN, 2010: 20) .

Porém, outra concepção, menos diabólica, do ofício do pesquisador aparece no horizonte sociológico: se, naquela visão, empírico e teórico se apresentam como duas ontologias constituídas por naturezas totalmente heterogêneas (e, portanto, naturalmente apartadas e só unidas pela pena do cientista social), aqui esses dois momentos se veem compostos pela mesma substância, sendo sua distinção apenas analítica. De igual maneira, o paralelismo no qual se articulavam é abandonado para que agora se reconheçam como um amálgama de mesma silhueta; e, finalmente, suas essências eternas e anteriores ao pesquisador são solapadas para que agora se experimentem como narrativas forjadas pelo próprio sociólogo. Essa visão não nega a existência do texto e do mundo, mas reconhece que, para o exercício de pesquisa, esses entes - que anteriormente eram o produto do trabalho - devem ser rearticulados e reconstruídos pelo ofício do sociólogo. Se antes competia ao pesquisador colher os fatos e as palavras, fazendo com que realidade e teoria falassem através de sua produção; agora cabe a ele reconstruir essas existências enquanto ferramentas de trabalho. $O$ produto final de antes 
vira a matéria-prima de agora, a evocação satânica e totalitária se reconhece como a tradução mortal e limitada, e assim, a sociologia cessa de ser a verdade sobre as coisas para se admitir como uma narrativa (assim como são narrativas seus objetos de estudo), e mesmo que ambicione ser categórica, reconhece a fortaleza de suas arestas. Se a pesquisa sociológica almeja ser um esforço compreensivo que intenta compreender a compreensão por meio da historicização de verdades, evidenciando a silhueta de narrativa e crença do que se apresenta aos homens como realidade (ou seja, como o mundo se mostra a quem o experimenta não como experiência, mas como natureza) deve a sociologia então, sob o risco de dar um tiro no próprio pé, admitir que é também uma experiência que analisa experiências, um momento historicamente situado numa trajetória, e não a verdade última sobre as coisas - verdade esta que, por negar às outras instâncias da vida, não pode cobrar para si. O que se defende aqui é uma igualdade formal (e não substancial) entre a sociologia e seus objetos de estudo: dizer que o texto sociológico possui particularidades conteudísticas (separando-se assim de outros textos) não nos impede de afirmar que existe uma equivalência posicional (que os aproxima); usando aqui um arranjo retórico extraído de Viveiros de Castro, pode-se dizer que a sociologia não é "um texto como os outros", mas certamente ela "é um texto, como os outros" (2002). Sua narrativa possui um conteúdo diferente das demais, mas se aproxima delas pelo fato de ser também uma narrativa. É dessa forma que o esforço de espelhamento que a matriz diabólica mantém com o mundo se vê abandonado em nome de uma atividade meramente reconstrutivista ao invés de realista. Se a verdade e eternidade da empiria e do teórico se veem negadas pelo esforço historicizante da sociologia, a possibilidade de englobar esses reinos também perde sentido; a tradução (sempre arbitrária, é verdade) se mostra como a alternativa ao realismo de antigamente.

Se cabe ao cientista social reconstruir o mundo e a tradição sociológica em seus textos (e não mais espelhá-los), percebemos que nessa matriz sociológica, os momentos de empáfia criadora e diabólica do pesquisador o obrigam, imediatamente, à mais sincera e cristã humildade: se pode o sociólogo refazer o mundo a seu bel prazer, objetivando o fluxo da vida da maneira que achar mais apropriada à sua pesquisa; sabe ele, no mesmo instante, que jamais poderá tocar esse fluxo, reproduzi-lo em sua continuidade sem lançar mão do corte arbitrário 
que é próprio ao seu ofício. Podemos reconstruir a vida com a cor que desejamos, mas jamais a alcançaremos em sua totalidade. Abdicamos do poder de reproduzir as coisas tal como são, para podermos reconstruí-las da maneira que quisermos. É nessa liberdade condicional, em que nos é dado o direito de objetivar o fluxo sem jamais espelhá-lo, que acredito residir o ofício de pesquisa em ciências sociais. Tal esforço parece ser a um só tempo - como diz a metáfora de Adorno e Horkheimer sobre a indústria cultural (2006) - pornográfico e puritano: por um lado ele nos excita ao dizer "tudo o que você quiser pode ser sociologia”, mas por outro rapidamente nos castra quando nos informa "mas desde que seja sociologia”. Ao contrário da embriaguez diabólica que só enaltece sem jamais refrear, essa concepção de ciências sociais, que oferece o céu como limite desde que não tiremos os pés do chão, se apresenta como uma alternativa mais honesta e menos perigosa na medida mesma em que faz das potencialidades da sociologia as suas próprias fronteiras.

Se a sociologia se configura pela desnaturalização de substâncias e pela historicização de verdades uma vez que intenta compreender compreensivamente a compreensão relativizando reinos até então absolutos, desnudando o construído no que se pensava ser eterno, percebe-se que seus avanços trazem em seu bojo o mais cristão autoflagelo; se o caminho sugerido pela sociologia neste esforço desconstrutivista se configura pelo desenrolar da razão na história, percebe-se imediatamente que a trajetória que a sociologia propõe a contêm, não sendo ela a origem da linha que ela mesma sugere. Sendo assim, quanto mais avança mais tem que se debruçar sobre si mesma. O trilho pelo qual as ciências sociais deslizam não é retilíneo, mas permeado por loopings, já que toda desconstrução de verdades operada pelo pesquisador resvala na própria constituição da disciplina, que se desacredita a cada nova conquista. Situamo-nos no caminho que propomos, e daí vem nossa esquizofrenia: à medida que avançamos devemos nos dobrar sobre nossa própria natureza para que esse avanço provocado por nossos esforços dialogue com nossa própria constituição.

Percebe-se aqui a insustentável dureza do ser sociólogo: enquanto todos os outros cientistas seguem apenas para frente, imputando, informando e nomeando; o sociólogo, uma vez que teve um produto de trabalho forjado pelo mesmo material de seus objetos de estudo, precisa, a cada passo para frente, a cada nova enunciação, olhar para trás com o objetivo de conformar aquele novo enunciado dentro da 
moldura que é seu ofício. A dificuldade de se escrever uma narrativa sobre um mundo que insistimos em apresentar como sendo uma narrativa, obriga a sociologia a carregar o fardo de ter uma silhueta autorreflexiva. Se somos os únicos que temos um ofício irmão do objeto, abdicamos de andar sempre pra frente para abraçarmos a trajetória oblíqua de afirmar e situar a afirmação no seio do exercício que a afirmou. Por traçarmos um caminho sinuoso num mundo em que todos apenas seguem em frente, rapidamente somos deixados para trás.

Ser obrigado a retroceder a cada novo avanço é, obviamente, um esforço demasiado fatigante. Da mesma maneira, ficar para trás enquanto assiste seus companheiros de ciência dispararem na corrida pela verdade é algo muito desconfortável. $\mathrm{O}$ pobre sociólogo passa a querer ter o prestígio dos outros cientistas. Preguiça, inveja e vaidade... um prato cheio para o satanás. Almas inocentes desgastadas pelo peso de sua profissão certamente aceitarão alguma proposta.

Pacientemente, o diabo bate a porta dos departamentos oferecendo o divórcio completo entre a natureza da disciplina e o conteúdo de seus enunciados, o hiato irremediável entre o objeto de estudo e o exercício de pesquisa, ou melhor dizendo, a fenda intransponível entre o produto e o processo de trabalho sociológicos. Se Deus é um sádico expectador da agonia humana que cria os instintos naturais apenas para em seguida forjar regras que os constranjam, o Diabo surge como aquele último grande humanista que presenteia seus seguidores não apenas com uma dimensão contemplativa dos prazeres, mas com a fruição desses em sua inteireza. Como Al Pacino ensina a Keanu Reeves: a culpa é uma mala cheia de tijolos, tudo o que temos que fazer é soltá-la e aí, finalmente, atingiremos o ideal de liberdade satânico de nunca ter que pedir perdão. Transportando essa metáfora para o âmbito sociológico, podemos perceber que a tentadora pergunta que o Diabo nos faz é: para que carregar o peso injustificado da reflexividade se podemos simplesmente abandoná-la e então, jamais precisaremos ficar constantemente nos justificando? Com essa cisão diabólica, livramo-nos do peso autorreflexivo das ciências sociais, não sendo mais necessário que se dialogue exercício com objeto; o ato de enunciação do texto sociológico se conforma como toda a esfera de seu ofício, as questões meta-discursivas (oriundas da esquizofrenia de ter a positivação, não como a vitória e o encerramento das atividades, mas sim como um fardo que traz novas dificuldades 
metodológicas) serão eternamente abandonadas. Enunciar verdades, promover consensos, atingir a perenidade, chegar onde eles chegaram... assinamos o contrato antes de atentarmos às letras miúdas.

Como nos ensina a sabedoria popular, o diabo é o pai da mentira e não pouparia nós sociólogos de seus ardis: o pesquisador que com o satanás trava contato lida com um mundo (tanto teórico como empírico) já pronto, natural, basta a ele apenas ligar essas duas esferas. A exaustão desse esforço interminável que vai e vem pouco se faz sentir perto do prazer por ele mesmo concedido: saber-se o nomeador universal, dono das palavras e do mundo, senhor das determinações, o alfabetizado no mundo dos leigos.

Em um reino em que teórico e empírico nos foram dados de presente pelo Diabo, essa esquizofrenia inexiste uma vez que o vetor é eternamente só de ida: mundo e sociologia são de duas naturezas, sendo o primeiro o significante que carece da mágica do segundo para fazer sentido, sendo este a própria verdade que se debruça sobre um universo sem nome para poder significá-lo. No satanismo metodológico, o mundo precisa do sociólogo e este não precisa de nada a não ser de si mesmo, não precisa se resignificar e pensar seu ofício, só ir em frente.
Este é um universo em que os objetos não foram criados pelos saberes que versam sobre eles, em que a natureza aguardou pacientemente pelos cientistas, um mundo em que a verdade sempre existiu e esperou por quem a desnudasse, em que nenhuma potência precisou amargar esse estado de latência e já nasceu enquanto ato.

O júbilo de levar uma vida assim é evidente: só prosseguir sem nunca se pensar, saber-se o guardião das palavras e das coisas em um universo de incerteza sem ter que amargar a esquizofrenia de um andarilho que quanto mais caminha mais retrocede já que é feito da mesma substância que o percurso que trilha. Talvez, intentando escapar de um árduo trabalho que parece levar sempre a contradição interna e ao retrocesso, muitos sociólogos vendem sua alma ao demônio em troca do benefício de ter um produto que nada prejudique o trabalho que o originou, um ofício que resulte num fruto que não obriga à ressignificação do esforço que o produziu. Esse eterno exercício de nomear exime o pesquisador de questionar a natureza de seu exercício. A grande dádiva do demônio é dar ao pesquisador um empírico e um teórico já terminados, e assim, ofício e objeto sociológicos se mostram com naturezas totalmente apartadas, a segunda carecendo da pri- 
meira, uma não prejudicando a outra: basta seguir feliz em frente, sem nada questionar.

Mas o que significaria construir em sociologia se seu esforço é tipicamente desconstrutivista? Se prega a desconfiança, como podemos confiar nela? O que é concreto e natural a uma disciplina que tem por função desconstruir e desnaturalizar? Que verdade é eterna nesse ofício que historiciza verdades e faz com que deixem de ser tais a seus olhos? Vender a alma ao demônio é se livrar do peso dessas dúvidas. Mas não seriam elas a própria especificidade da disciplina? A força motriz do exercício sociológico não residiria no momento em que esse saber se debruça sobre si mesmo enquanto metanarrativa?

No desejo de se livrar das inquietações próprias ao ofício sociológico, o pesquisador acende sua vela para o demônio e acaba abraçando um mundo de prazeres na medida mesma em que abre mão do desejo para se conformar à felicidade demoníaca de um mundo meramente geográfico de representações prontas. A ganância do satanista acaba fazendo com que ele abra mão da sociologia em nome dela: é pouco para ele um saber que se constrói na medida em que se questiona, é necessário algo pronto, um produto que não resvale na sua produção. Livrar-se das inquietações que a sociologia nos provoca é uma tentadora proposta que o Diabo nos oferece, mas o que a vaidade, a preguiça e a inveja (talvez os pecados preferidos Dele) não nos deixam ver é que talvez as dificuldades da sociologia sejam a morada de sua essência. Se a sociologia é, antes de tudo, um saber compreensivo, fazer com que ela deixe de se compreender é justamente abandona-la para sempre. Escolher o realismo em detrimento da compreensão (ou o positivismo no lugar da autorreflexividade) é virar as costas eternamente para o próprio ofício, justamente quando se achava que estávamos exercendo-o em sua inteireza. Quando optamos por receber pronta e acabada uma ciência que é, na verdade, construtivista (e se constrói na medida em que se faz) não percebemos que demos nossa alma em troca de uma embalagem vazia. Abraçamos a representação em detrimento da reconstrução, e assim, deixamos de ser sociólogos quando achávamos que finalmente o seriamos de maneira plena.

Se a sociologia se faz construtiva e não representativamente, é necessário que ela nunca dê por concluída sua obra, caso contrário será extinta. Para que o desejo de ser sociólogo continue nos movimentando, ele nunca pode ser satisfeito. É na angústia que se pratica o exercício sociológico, para isso, o nome deve sempre ambicionar tocar a coi- 
sa, a vontade deve sonhar ser ordem, mas quando esse arco está quase se cumprindo e a sociologia está prestes a enunciar suas verdades, ela olha para trás e se debruça sobre si mesma, questionando o próprio exercício de questionar exercícios. É nessa tensão, constantemente atravessada por um desejo que por nunca se cumprir eternamente se promete, que acredito residir o ofício sociológico. $\mathrm{O}$ pacto demoníaco que nos livra desse peso e nos oferece uma pátina tranquila para exercermos nossa atividade tira dela o que lhe é mais próprio; esse eterno nomear que nunca se questiona cumpre o ideal diabólico de uma construção que nada instaura, um fazer que apenas desconstrói sem nada colocar no lugar. No fim das contas, vitimizados por um ventriloquismo satânico, percebemos que fomos apenas marionetes do diabo sem termos um trabalho para chamar de nosso. Almejando-se atingir a totalidade de nosso potencial, acabamos por abdicar da especificidade da nossa disciplina, e enquanto soberbamente damos nomes às coisas nesse ofício que nada cria uma vez que apenas toscamente representa, o demônio ri às gargalhadas esperando o dia em que nossa alma será definitivamente dele. As incertezas de nossa profissão podem ser o que há de mais fundamental no nosso ofício, talvez sejam elas que nos lancem sempre mais adiante, ainda que de maneira muito árdua. Como disse anteriormente, talvez as potencialidades da sociologia sejam também seus limites, e essa percepção só é atingida nesse ato de renunciar olhar sempre pra frente para que se se debruce sobre si mesmo captando uma homologia substancial entre produto e exercício, necessidade do saber e este próprio.

Na matriz satânica a natureza sobre a qual o sociólogo versa é anterior ao seu discurso sobre ela, sendo assim, cabe ao cientista apenas "descobri-la”; aqui seu trabalho é de constatação. Nesse caso, o objeto da ciência é eterno e verdadeiro, embora cifrado; dessa forma, a relevância do trabalho de pesquisa se vê naturalmente justificada, o pesquisador passar a ser absolutamente necessário. Mas a postura que defendemos é que o objeto sociológico não antecede o texto científico que versa sobre ele, pelo contrário: sua construção é simultânea à elaboração da narrativa que o tematiza. À medida que o discurso sobre a coisa vai se articulando, também vai ganhando corpo a coisa sobre a qual se discursa. Dessa maneira, não cabe ao cientista "descobrir" a natureza, mas "inventá-la”. Seu trabalho deixa de ser de constatação e passa a ser de “criação". Aquela necessidade natural e absoluta que se tinha do cien- 
tista desaparece, mas em seu lugar surge uma nova socialmente construída e historicamente burilada: a relevância da pesquisa sociológica deixa de ser a de explicar o mundo para ser a de constituí-lo. Aquela segurança demoníaca de que a realidade sublinhava nossos escritos deixa de existir, mas, em compensação, agora podemos requerer a autoria dessa mesma realidade. $\mathrm{O}$ ofício que antes era seguro e reprodutivo passa a ser arriscado e produtivo. No conforto só havia espelhamento, mas em contrapartida o risco se revelou a morada da criatividade. Sendo assim, não podemos perder de vista a noção de que a relação entre ciências e suas naturezas (ou entre os saberes e seus objetos) é de mútua implicação: uma constrói a outra no instante em que se constrói, formando assim um arranjo recursivo de criação recíproca.

"De fato, poderíamos dizer que um antropólogo 'inventa' a cultura que ele acredita estar estudando, que a relação - por consistir em seus próprios atos e experiências - é mais 'real' do que as coisas que ela 'relaciona'. (...) No ato de inventar outra cultura, o antropólogo inventa a sua própria e acaba por reinventar a própria noção de cultura. (...) Assim sendo, já que todo esforço para conhecer outra cultura deve no mínimo começar por um ato de invenção, o aspirante a nativo só conseguirá ingressar num mundo criado por ele mesmo. (...) $O$ estudo ou representação de uma cultura não consiste numa mera descrição do objeto, do mesmo modo que uma pintura não meramente 'descreve' aquilo que figura. Em ambos os casos há uma simbolização que está conectada com a intenção inicial do antropólogo ou do artista de representar seu objeto."(WAGNER, 2010: $30-40$ ).

"Geralmente se supõe que a nossa cultura, com sua ciência e sua tecnologia, opera medindo, prevendo e arregimentando um mundo de 'forças' naturais. Na realidade, porém, todo o nosso leque de controles convencionais, nosso 'conhecimento', nossa literatura sobre realizações científicas e artísticas, nosso arsenal de técnicas produtivas, são um conjunto de dispositivos para a invenção de um mundo natural e fenomênico. Ao assumir que apenas medimos, prevemos e arregimentamos esse mundo de situações, indivíduos e forças, mas- 
caramos ofato de que o criamos. (...) O aspecto significativo dessa invenção, seu aspecto convencional, é que seus produtos precisam ser tomados muito seriamente, de modo que não se trate absolutamente de invenção, mas de realidade. Se o inventor mantém firmemente essa seriedade em mente (como uma 'regra de segurança', pelo menos) enquanto faz seu trabalho de mediação, previsão ou arregimentação, a experiência da 'natureza' resultante irá sustentar suas próprias distinções convencionais. (...) A ciência, do mesmo modo, introduz 'sistema' na natureza e depois se deleita em descobri-lo ali; ela imprime uma forma sistêmica aos fenômenos naturais, $e$ uma inevitabilidade natural a suas teorias." (Ibid.: 123 -125).

\section{Verdade: universalidade e contexto}

Quando optamos pela reconstrução compreensiva em detrimento do realismo positivista, nossa narrativa pode definir o mundo da maneira que quiser, mas jamais dirá como ele é de fato. E existiria mesmo esse mundo "de fato", de verdade, para além das narrativas acerca dele? É necessário que se precise aqui o que se entende por "verdade". Esse ensaio em nenhum momento defendeu a presunçosa meta do abandono do conceito de verdade. O que aqui se quis foi apenas fazer um convite para que se questione o estatuto ontológico dessa ideia. Se quisermos ser fieis a natureza compreensiva das ciências sociais acredito que a concepção de verdade deve (1) ser inatingível e (2) não ser universal. Sobre ser inatingível, me refiro ao fato de que o cientista social deve sempre ter a pretensão de atingir a verdade, mas nunca cair na perigosa certeza de que a alcançou. Sendo assim, a verdade deve se apresentar para o sociólogo sempre enquanto uma pretensão e nunca como uma presença, ou seja, conformando-se mais como um inatingível referencial do que sob a forma de um artefato conquistado. Verdade aqui não é sinônimo de realidade, muito pelo contrário, mas antes uma pauta normativa orientadora historicamente construída, esvaziada de qualquer substancialidade ou imanência. Quando afirmamos que a verdade é inalcançável, não nos propomos a cunhar uma máxima moral; apenas se quer insistir que a verdade só pode se fazer presente enquanto uma infinita meta futura, uma esfumaçada referência que só pode se apresentar, do começo ao fim, enquanto uma vontade. Sobre não ser universal, 
3 A referência clara aqui é o Perspectivismo de

Viveiros de Castro e sua noção de "multinaturalismo" como um acréscimo ao já canonizado "multiculturalismo": não se tem apenas uma infinidade de narrativas culturais sobre uma mesma natureza, mas também uma pluralidade de respectivas naturezas analisadas por cada uma daquelas culturas. Se o multiculturalismo defende uma unidade de corpos em favor de uma multiplicidade de espíritos; o multinaturalismo age no sentido contrário, advogando um monismo espiritual que permanece velado sob a pluralidade dos corpos, que assim funcionam como "roupas" variadas do espírito unívoco. (VIVEIROS DE CASTRO, 2002). referimo-nos a fato de que não estão todos os sociólogos tomando por referência uma mesma pretensa imagem de verdade. No quadro analítico de cada pesquisador se vê sugerido não apenas um percurso para se atingir um fim, mas a própria coloração desse ponto de chegada. Mesmo quando tecem seus comentários mais universalistas ou gerais, não podem os pesquisadores negligenciar o fato de que versam sobre universalidades por eles forjadas. Nos instantes de megalomania em que ambicionamos abraçar o mundo, devemos ter em mente que estamos tentando ter nas mãos um mundo que propomos, e que já não é o mundo que outro sociólogo propôs e também quer abraçar. Além de sugerir modos de abordagem analítica das coisas, os sociólogos sugerem também a silhueta dessas tais coisas a serem analisadas pela abordagem proposta: construímos maneiras de ver o mundo e um mundo a ser visto por aquela maneira. $O$ pesquisador inventa a chave e a fechadura, mas se esquece desse segundo feito e se deleita em ter burilado a chave ideal para aquela fechadura "natural". Os cientistas sociais estão muito acostumados com a ideia de que existem várias "visões de mundo", mas ainda não abriram mão da certeza de que existe um mundo só. Se o que temos são diversas "visões de mundo" de um mes- mo mundo, então se deve admitir que apenas um desses pontos de vista está correto e que aos outros só é reconhecida a existência se eles se admitirem como equivocados. Quando afirmamos a existência de uma pluralidade de narrativas analíticas sem um simultâneo reconhecimento de que se tem uma respectiva pluralidade de substâncias analisadas por aquelas narrativas, tudo o que conseguimos foi criar uma ferramenta de validação da nossa perspectiva. O maior feito dessa escola foi instaurar um relativismo epistemológico desfalcado de um relativismo ontológico e, assim, criar a engrenagem satânica que se admite relativa ao mesmo tempo em que forja a universalidade do gabarito avaliativo que sempre a referenda, tornando-a igualmente absoluta.

Em um cenário onde existem várias versões de um mesmo fato, o que se tem é uma falsa pluralidade, pois de nada adianta a multiplicidade das versões se a unicidade do fato se presta a encontrar a versão que lhe espelha com fidelidade e assim, altera seu estatuto existencial, transubstanciando-a de versão em fato. De que adiantam leituras variáveis se há apenas um texto invariante que, invariavelmente, ratificará a variável que o ratifica? ${ }^{3}$ O que era um ponto de vista sobre a coisa, acaba virando a própria coisa; a perspectiva, que era da ordem do juízo, 
4 É sobre essa mesma problemática que versa Bauman ao insistir no caráter legislador do intérprete, salientando que a interpretação não é uma opção à legislação, mas uma responsabilidade quanto aos limites e à contextualidade desse exercício:

"Eles [os intérpretes] mantêm aqui sua autoridade metaprofissional, legislando sobre as regras de procedimento que possibilitam arbitrar controvérsias de opinião e fazer afirmações de vocação vinculante. A dificuldade nova, contudo, é como estabelecer as fronteiras de tal comunidade de modo que sirvam como território de práticas legislativas." (BAUMANN, 201O: 2O) passa para o plano da natureza. Como diz Marx a respeito da mágica fetichista da mercadoria:

"Assim, a impressão luminosa de uma coisa sobre o nervo ótico não se apresenta como uma excitação subjetiva do próprio nervo, mas como forma objetiva de uma coisa fora do olho." (MARX, 2008: 23).

Para os adeptos dessa corrente, de nada vale possuir a verdade se não existir o correspondente exército de equivocados. Temendo virar um rei sem reino, o satanista afirma que existem outras visões parciais como a sua, mas que há apenas um artefato universal a ser analisado por aquelas várias parcialidades e que, “coincidentemente”, é simétrica a sua "visão parcial", que assim deixa de ser visão para se tornar espelho. Como dito anteriormente, não se pode acreditar que a natureza (ou o objeto) antecede o saber que versa sobre ela e que assim, tal natureza se encontrava em um estado de incompletude, aguardando o surgimento da narrativa que, ao estudá-la, completá-la-ia. Existe uma mútua afinidade entre o texto analítico e o objeto analisado em que ambos se constroem reciprocamente até que se nivelam no mesmo estatuto ontológico de narrativa.
Construindo seu objeto, o saber não só constrói a si mesmo, como também constrói a necessidade que temos dele, estando essa necessidade longe de ser uma carência a-histórica. O que há de comum entre a proposta de verdade de um sociólogo e de outro é apenas que ambas são propostas de verdade, porém, respectivas propostas de verdade. Sua semelhança é que ocupam um mesmo patamar epistemológico em cada quadro de análise, mas de forma alguma possuem o mesmo contorno. Com isso não se quer aqui propor que os cientistas sociais admitam um tom menos universalista, mas apenas que não negligenciem o fato de que versam sobre universos contextualmente desenhados ${ }^{4}$, generalidades localmente concebidas ${ }^{5}$.

"A impossibilidade de penetrar no esquema divino do universo não pode, contudo, dissuadir-nos de planejar esquemas humanos, embora conste que estes são provisórios" (BORGES, 2007: 125).

Como sugerido na epígrafe desse ensaio, para continuarmos com Borges ${ }^{6}$, cabe perguntarmo-nos: se nem o conceito de universo é universalmente compartilhado, porque o seriam as narrativas com pre- 
5 O próprio enunciado de que se deve "acreditar na existência da verdade" já é em si bastante contraditório; uma vez que a verdade - absolutamente concebida - não pode carecer de crença para existir, ela se impõe aos juízos de maneira concreta. Se é necessário que acreditemos nela para que seja verdade, trata-se apenas de uma crença generalizadamente compartilhada enquanto verdade, e não esta propriamente dita.

6 A título de curiosidade: as passagens de Borges contidas nesse texto foram retiradas do ensaio "O Idioma Analítico de John Wilkins” que traz a referência à enciclopédia chinesa que tanto inspirou Foucault na escrita de "As Palavras e as Coisas".

7 “O universo social é o lugar de uma luta para tensão de verdade universal que se produzem sobre esse universo?

"É possível suspeitar de que não haja universo no sentido orgânico, unificador, que tem essa ambiciosa palavra. Se houver, falta conjecturar sobre o seu propósito; falta conjecturar sobre as palavras, as definições, as etimologias, as sinonímias do secreto dicionário de Deus."(ibid.).

Portanto, se quisermos que nossas verdades sejam universais é preciso ter em mente que existem outros universos, cada um com sua respectiva verdade governando-o. As subjetividades não gravitam em torno de uma mesa objetividade: para cada subjetividade há sua respectiva objetividade.

"Indivíduos criados em sociedades diferentes comportam-se, em algumas ocasiões, como se vissem coisas diferentes. Se não fôssemos tentados a estabelecer uma relação biunívoca entre estímulo e sensação, poderíamos admitir que tais indivíduos realmente veem coisas diferentes. Note-se que dois grupos cujos membros têm sistematicamente sensações diferentes ao captar os mesmos estímulos vivem, em certo sentido, em mundos diferentes" (KUHN, 2011: 241).

E para além de cada proposição de verdade, não haveria uma que paira acima de todas à qual os sociólogos poderiam recorrer para descobrir, afinal, quem está certo? Acredito que não. Mais razoável seria crer que tal realidade natural, absoluta, eterna e anterior aos discursos que versam sobre a verdade seria antes uma narrativa instaurada pela busca por esse artefato virginal: o "mundo" mora na linguagem, mas também mora lá a sensação de que ele está fora dela. A pureza e o absolutismo dessa dita realidade já nasceram manchadas de história, ficção e contextualidade. A corrida, portanto, não é para saber quem está mais próximo desse ideal puro de verdade, mas sim para definir quem está mais apto a definir a silhueta dessa ideal: uma disputa em que o que está em jogo é quem ocupará a posição de juiz desse mesmo jogo que se disputa. Não se trata de convencer o árbitro, mas sim de arbitrar7. Além do mais, se estudamos a compreensão (ou seja, se nos debruçamos menos sobre as coisas do que sobre a forma com que estas são experimentadas), que relevância metodológica teria esse artefato que não 
saber o que é o mundo social. A universidade também é o lugar de uma luta para saber quem, no interior desse universo socialmente mandatário para dizer a verdade sobre o mundo social (e sobre o mundo físico), está realmente (ou particularmente) fundamentado para dizer a verdade. Essa luta opõe os sociólogos e os juristas, mas também opõe os juristas entre si e os sociólogos entre si. Intervir enquanto sociólogo significava evidentemente ser tentado a usar a ciência social para se colocar como árbitro ou juiz nessa luta, para distribuir erros e acertos. Em outros termos, o erro estruturalista, que consiste em dizer: 'eu sei mais do que o indígena o que ele mesmo é'), esse erro era a tentação por excelência para alguém que, sendo sociólogo e, portanto, inscrito em um campo foi tocado por nenhuma experiência? Sinceramente, eu não sei.

Como foi exaustivamente pontuado nesse ensaio, acredita-se aqui que a sociologia é feita da mesma matéria que os objetos que estuda, que é um discurso que se debruça discursivamente sobre outros discursos ${ }^{8}$. Certamente, essa espiral eterna de metarreflexividade traz à superfície as dificuldades do exercício sociológico, mas talvez seja essa a condição necessária de sua sobrevivência. Optar por um positivismo nomológico pode ser mais cômodo, porém certamente mais vazio. No primeiro caso renunciamos ao estatuto de verdade universal do cosmos, mas garantimos nossa posição de narrativa autocompreensiva. No segundo, soberbamente afirmamos que abraçamos toda a realidade, mas com isso findamos por esquecer que, ao conter todo o real, acabamos por nos situarmos fora dele.

Mas se os sociólogos divergem tanto no que diz respeito à maneira de se estudar um objeto, bem como no que tange a constituição morfológica de tais objetos, como podem esses cientistas ainda poderem dialogar sem cair numa verdadeira Torre de Babel? Ou, dito de maneira ainda mais enfática, como a sociologia consegue se perpetuar no quadro das ciências com uma silhueta tão monolítica e esta- belecida? Essa tensa unidade das ciências sociais é possível porque, mesmo que tenhamos abdicado de instaurar consensos morfológicos, ainda nos preocupamos com o equilíbrio formal do nosso diálogo. Acredito que a sociologia não caminhe rumo ao estabelecimento de verdades imutáveis e universalmente compartilhadas, mas sim nos trilhos de um crescente ajuste dos discursos para que se tenha um idioma possível, ainda que cortado por diferentes sotaques. As propostas analíticas de cada sociólogo podem não trazer grandes afinidades substanciais, mas certamente evidenciam aproximações posicionais: o "Fato Social" durkheimiano, o "Campo" de Bourdieu ou o "Sistema" de Parsons podem ser ontologicamente diferentes, mas analiticamente simétricos. Tais noções apresentam diferentes constituições morfológicas, mas possuem a mesma importância relativa e ocupam a mesma posição analítica nos respectivos modelos compreensivos de cada um desses autores. Dito de forma mais exemplificada: é claro que as definições dos conceitos de Fato Social, Campo e Sistema são totalmente diferentes, mas não seria incorreto dizer que o conceito de Fato Social está para os demais conceitos durkheimianos assim como o de Campo está para as outras definições de Bourdieu da mesma forma que a ideia de 
de luta pela verdade, adotava como projeto dizer a verdade desse mundo e dos pontos de vista opostos sobre esse mundo." (BOURDIEU, 1990: 116).

8 "Uma das coisas mais frequentemente esquecidas é que qualquer pessoa que fale sobre o mundo social deve contar com o fato de que no mundo social fala-se do mundo social, e para ter a última palavra sobre esse mundo que o mundo social é o lugar de uma luta pela verdade sobre o mundo social." (Ibid.)

9 Fazendo referência mais uma vez a Viveiros de Castro: o que se tem aqui é mais uma "geometria das relações" que uma "física das substâncias”. (VIVEIROS DE CASTRO, 2011: 291)
Sistema se apresenta para o restante das categorias de Parsons. Na ausência de um gabarito de certeza (que necessariamente não pode ter sido forjado por cientista nenhum) que situe cada sociólogo mais próximo ou mais distante dessa pauta normativa, os pesquisadores se esforçam por construir certas simetrias posicionais em seus respectivos paradigmas reflexivos para que atinjam uma equidistância entre si e possam se entenderg.

Essa simetria posicional das categorias analíticas que permite que os sociólogos dialoguem mesmo quando propõem mundos e modos de abordar o mundo tão diversos é auxiliada, em grande parte, por aquela noção de verdade compreendida como uma eterna meta futura, que se promete sem nunca se cumprir, constituindo-se mais como desejo ou pretensão do que como presença. Porém, e aqui é necessário que se pontue isso, não podemos acreditar que exista uma anterioridade lógica ou cronológica dessa verdade futura em relação aos arranjos discursivos simétricos que desejam abarcá-la. Voltar à metáfora do idioma e seus sotaques (ORTIZ, 2008) é relevante para que se entenda esse modelo: seria incorreto afirmar que o idioma antecede seus sotaques, ou conceber que esses sejam meras variações dessa linguagem primitiva e matricial. É a diversidade dos sotaques que cria a necessidade de que estes se arranjem de maneira equidistante, forjando um eixo comum a todos eles para que assim, possam se entender enquanto uma mesma língua. A língua (pura e unitariamente concebida), essa espinha dorsal que atravessa os sotaques, é desenhada pelas intersecções que resultam de seu alinhamento. Aquilo que pode parecer o fio condutor linguístico que arregimenta todos os sotaques é, na verdade, o resultado do entrecruzamento desses sotaques que desejam se fazer entender entre si enquanto idioma. Da mesma forma, essa visão monolítica de verdade científica que se pretende abarcar é um produto das interfaces dos diversos arranjos compreensivos de cada pesquisador. Se a silhueta continuada do idioma é forjada pela sobreposição de rupturas dos sotaques, a verdade sociológica que escapa a todos os sociólogos nada mais é que o amálgama de todos os seus textos: o que parecia não pertencer a nenhum dos pesquisadores foi rascunhado por cada um deles. A verdade puramente concebida e eternamente buscada se apresenta como a junção das várias buscas realizadas para alcançá-la. O vetor da corrida define a localização do ponto de chegada, que por sua vez orienta a direção desse mesmo vetor. A relação entre verdade e bus- 
ca da verdade deve ser reflexivamente rascunhada, recursivamente concebida, uma vez que a unicidade do puro é um hibridismo mantido pela sobreposição de pluralidades.

Prosseguindo com a analogia: existem muitas maneiras de se falar português, nenhuma delas é "certa" ou "errada", mas cada uma delas é enviesada, contextual e parcial. Cada maneira dessas é característica da região em que é falada, representando assim uma parte específica do Brasil; e nenhuma delas consegue, metonimicamente, representar por si só o país inteiro. Dizer isso não é afirmar que seja impossível se chegar a um português "objetivo", universal e que, desnudado das marcas da contextualidade, represente o Brasil como um todo. Sim, esse empreendimento é viável, mas não se pode achar que ele será atingido na busca por um português desenraizado que paire acima dos "portugueses" específicos, ou seja, um português sem sotaque. Pelo contrário: o português objetivo que espelhe a totalidade Brasil será alcançado quando se sobrepuserem todos os sotaques, fazendo com que a sucessão dessas heterogeneidades construa um contínuo liame homogêneo. Assim, a língua universal depende de cada uma das propostas particulares de língua, mas não é uma maximização fiel de nenhuma delas. Nenhum sotaque pode se dizer a miniatura perfeita do idioma geral, mas também não há um sotaque sequer que não tenha contribuído para o desenho dessa grande unidade linguística. De igual maneira, a verdade científica geral e objetiva não pode ser imaginada como um corpo que flutua sobre as muitas sugestões de verdade, mas antes como o retrato compósito (BATESON, 2008) formado pela sobreposição dessas sugestões.

"A solução final do problema apresenta-se, então, de tal forma que somente após a justaposição dos diferentes modos de conhecimentos e de suas respectivas epistemologias é que se pode elaborar uma epistemologia mais fundamental e inclusiva" (MANNHEIM, 1972: 312).

"O problema consiste não em tentar esconder estas perspectivas ou em se desculpar por elas, mas em formular a questão de como, dadas tais perspectivas, o conhecimento e a objetividade são ainda possíveis. Não é uma fonte de erro que, na figura visual de um objeto no espaço, somente possamos, pela natureza da situação, obter uma visão perspectiva. $O$ 
problema não é o de como poderíamos chegar a uma figura não-perspectiva, mas o de como, pela justaposição dos vários pontos de vista, se pode reconhecer cada perspectiva como tal, atingindo-se, dessa forma, um novo nível de objetividade. Chegamos, assim, ao ponto em que se deve substituir ofalso ideal de um ponto de vista desvinculado e impessoal pelo ideal de um ponto de vista essencialmente humano situado dentro dos limites de uma perspectiva humana, em constante esforço por se alargar.” (Ibid.: 316 - 317).

Assim como não existe uma língua asséptica desnudada de seus sotaques (um português verdadeiro, por exemplo), também a verdade científica universal e imaculada que paira acima da narrativa de cada pesquisador é uma miragem sustentada justamente pela interface das narrativas de cada um deles.

“A ordem não precede as práticas e, por conseguinte, não pode servir como medida externa de sua validade. Cada qual dos muitos modelos de ordem só faz sentido em termos das práticas que os validam. Em cada caso, a validação introduz critérios que são desenvol- vidos no interior de uma tradição particular; eles são sustentados pelos hábitos e crenças de uma 'comunidade de significados' e não admitem outros testes de legitimidade." (BAUMAN, 2010: 19).

Se o ente metafísico que parece sobrevoar os nossos textos só tem essa feição justamente porque é uma encruzilhada discursiva desses próprios textos, então não se pode abraçar a verdade, já que toda proposição acerca dela (por partir de seu interior e constituí-la) nunca deixa de ser uma alteração de sua silhueta: querer abarcar um real que nos abarca - ainda que pareça estar acima de nós - é como querer se antecipar à própria sombra.

\section{Conclusão: mimesis e poiesis}

No longo e talvez infinito percurso para virar um sociólogo pleno, o jovem pesquisador se depara com uma bifurcação. De um lado, temos o acesso a esse pretenso mundo real, a possibilidade de que se deite as palavras sobre o solo maciço da verdade; do outro a autorreflexão, a metalinguagem que faz a sociologia esquivar-se desse investimento direto para fora de suas muralhas de sentido para que possa voltar-se sobre si mesma, assentando seus enuncia- 
10 "Não há critério para avaliar práticas locais que estejam situados fora das tradições, fora das 'localidades'. Sistemas de conhecimento só podem ser avaliados a partir 'do interlocutor' de suas respectivas tradições.” (BAUMANN, 2010: 19). dos sobre a superfície semântica que os enunciou. Em outras palavras, trata-se de uma opção entre o positivismo e a autocompreensão. Para muitos, essa díade pode se conformar enquanto uma escolha - dito de maneira respectiva - entre o realismo concreto e o isolamento autorreferente. Mas, se estivermos corretos no percurso que aqui desenvolvemos, então as narrativas só fazem sentido à luz delas próprias, dialogando entre si na medida em que fazem interseccionar suas simetrias posicionais, e não porque se veem iluminadas por um imutável e eterno sentido que paira acima delas todas: cada sentido existe dentro das fronteiras simbólicas de seu respectivo círculo linguístico, fronteiras essas que se sobrepõem, possibilitando a conversação; mas fora dessas fronteiras e para além de suas interpenetrações que se projetam em horizontes de verdade não se pode contar com um sentido absoluto que a todos abarca. Há quem acredite que exista um platô retangular de rígidas arestas e sólidos ângulos ortogonais. Para esses, as paredes do platô contém círculos linguísticos simetricamente enfileirados e separados de maneira equidistante. Acreditam que esses círculos são moradas autocontidas, contextuais, localizados onde habitam os homens de pensamento limitado e temático. Mas, aqueles que têm essa crença têm também a certeza de que não habitam círculo nenhum; acreditam eles que moram no platô retangular estrutural e generalizado que sustenta todos os círculos e que de lá eles circulam entre as respectivas redomas de sentido, contemplando-as de fora, de uma perspectiva global e desenraizada. Mas, o que esse ensaio defende, é que o platô não existe: tudo o que há são os círculos semânticos interseccionados com seus diâmetros variados sempre variando sem deixar brecha para o surgimento desse solo comum, sem permitir frestas aonde venha se inscrever a estrutura desterritorializada universal. Se os círculos dialogam não é porque se deixam sustentar por um constructo generalizado que não pertence a domínio nenhum, mas porque se sobrepõem, fazendo de suas interfaces os tropos de conversação possível. Não há estrutura, só intersecção. Dito de maneira definitiva, (de um ponto de vista da relevância sociológica) fora das esferas compreensivas, não há nada ${ }^{10}$. Dessa forma, recusar o oblíquo movimento metalinguístico de se dobrar sobre si mesmo para que se se projete de maneira direta para fora de seu perímetro nos rumos desse inexistente real absoluto nada mais é que abandonar a certeza e a solidez da autocompreensão para que se abrace a promessa de uma falsa "re- 
11 Vê-se repetido aqui o mesmo binômio teatro/ usina, abordado em "O Anti-Édipo": para os autores, a psicanálise trata o inconsciente como sendo o teatro figurativo que tem por função apenas reproduzir, imitar as formas "pai-mãe-eu" do triângulo edipiano. Mas, para a proposta esquizo-analítica que sugerem, o inconsciente é usina, não cabendo a ela copiar nenhum paradigma que lhe seja exterior, mas sim criar suas próprias formas, entregar-se ao seu próprio fluxo desejante plurívoco maquínico de produção, registro e consumo de invenção fluida. (DELEUZE GUATTARI, 2010). alidade", literalmente, sem sentido. Para que sair do círculo para o platô se, do lado de fora, não há platô, mas apenas outros círculos se cortando, alargando suas arestas através da pulsação de seus diâmetros? E mesmo que platô houvesse, para que tentar reproduzir figurativamente suas imagens externas, se poderíamos produzir as nossas interiores? Ambicionar reproduzir essa pretensa realidade exterior em detrimento de se se debruçar sobre a própria natureza é preferir a representação em detrimento da criação. Ou seja, abdicamos de instaurar o nosso texto para apenas repetirmos um que, sem nem sequer sabermos se existe, soberbamente acreditamos que poderíamos conter. Nessa encruzilhada (e não haveria lugar mais adequado para o desenlace da nossa metáfora) os caminhos que se cruzam são o da produção e o da reprodução. Dessa maneira, para o argumento aqui desenvolvido, percebe-se que é na natureza autorreflexiva e metalinguística das ciências sociais que repousa seu potencial criador, produtor; por outro lado, abdicar dessa virada reflexiva sobre si mesmo, é escolher a repetição do nada, optar por ser o eco de uma inexistente voz originária. Não devemos querer reproduzir no interior do perímetro do nosso círculo linguístico os sentidos externos do inexistente platô generalizado; o que devemos fazer é instauramos nossos próprios sentidos dentro dos domínios de nosso locus de significado e tentarmos alargar seu diâmetro. Sendo assim, aquela bifurcação que obriga o sociólogo a escolher entre o positivismo e a autocompreensão não é, como acreditam muitos, uma dúvida entre o "realismo concreto" e o "isolamento autorreferente", mas entre a reprodução do nada e a produção de sentido, a expressão e a criação, a citação e a fala ou, dito de forma ainda mais direta, entre a mimesis e a poiesis ${ }^{11}$.

Abraçar a repetição em detrimento da criação é defender que o exercício sociológico se presta a depurar, enxugar os símbolos até que se chegue ao artefato puro e eterno a ser reproduzido. Sendo assim, caberia ao pesquisador apagar o sentido, dissipar a linguagem para que se acesse esse pretenso real que deve ser copiado. Porém, ao afirmar que o ofício sociológico é mais criador que figurativamente mimético, defende-se que cabe ao sociólogo instaurar sentido, polissemizar, sobrepor texto a textos já sobrepostos sobre outros. Mais do que escrever uma narrativa sobre um artefato, escrevemos narrativas sobre narrativas escritas. Se aqui estivermos corretos, o gesto sociológico não é o de economizar até que se chegue à sensata obviedade da ontologia 
monolítica, mas ser excessivo, exagerar para que se atinja a variedade fluida dos sentidos polifônicos. A pedra de toque dessa ciência não é varrer a folhagem simbólica que recobre um mundo pré-existente para saber como ele "de fato é", mas derramar outro mundo em cima deste. A linguagem e as narrativas não são uma neblina que turva nossa visão do mundo, mas a parte do mundo que nos interessa; e nos interessa não enquanto produto final de nosso ofício, mas como matéria-prima de nossos esforços. Se os círculos não vivem sob a ditatura do "realismo" do platô, mas sim sob suas próprias leis simbólicas, então se deve acabar com essa herança. Criar, e não repetir. Não se trata de fazer uma "sociologia realista", mas de "sociologizar o real".

Transbordar as próprias fronteiras, fazer sangrar com o jorro do nosso discurso as muralhas da barragem que represa nosso ofício, é um objetivo extremamente legítimo e que invade o espírito do profissional sério de qualquer área. A questão sugerida por esse ensaio foi a de como fazer isso. Não se quis aqui pregar uma estéril modéstia que nos amarra a um conformismo paralisante, muito pelo contrário: o texto teve por objetivo, justamente, explorar as potencialidades da sociologia, jogando luz sobre tudo o que podemos ser. Mas, se o que se quer é ir além, faz-se necessário que não se confunda a linearidade do percurso com seu alcance: muitas vezes, a linha reta em que caminhamos cada vez mais rápido nos conduz apenas ao nada, e o caminho oblíquo e que, em alguns momentos, parece nos arrastar para a direção contrária, pode ser aquele que nos leva sempre mais longe. Aumentar a capacidade da própria disciplina é algo muito positivo, mas só o é se as novas conquistas não vierem acompanhadas de uma renúncia do que já se possui. Se isto for correto, não se pode chamar de progresso científico a adoção de um pretenso realismo representativo que obriga o necessário abandono da autorreflexão criadora. Não há porque negligenciar a solidez autocompreensiva em nome da incerteza do que se encontra "do lado de lá". Se o que temos, em última instância, são círculos de linguagens possíveis, cruzar o contorno desses círculos é ir aonde a língua não vai, atirar-se no vácuo em que o som não se propaga. Para que se conquistem novos domínios sem que percamos aquele que já é nosso, talvez o melhor caminho não seja a colonização de outros territórios, mas o aumento do alcance de nossa visão: já que não podemos conter o horizonte, vamos ampliá-lo. Talvez, na luta simbólica pelo avanço científico, as verdadeiras conquistas não sejam geo- 
gráficas, mas de perspicácia. A meta não é ter o real nas mãos (pois isso significa nos posicionarmos fora dele), mas projetarmos sempre mais longe nossos horizontes de verdade. Não se trata de avançarmos nossos limites, mas de afastá-los sempre mais: se ao cruzarmos as fronteiras que conformam nosso círculo linguístico nos conduzimos para o lado de fora onde não há nada, então, ao invés de saltarmos esses muros simbólicos, o que devemos fazer é empurrá-los para mais longe.

Como se disse, nós podemos até morar em um mundo de verdades universais e absolutas, mas não podemos perder de vista que estas são universalidades localmente forjadas, absolutismos relativamente construídos e que existem outros mundos com suas respectivas generalizações. As verdades não se propagam porque aumentam de tamanho, constrangendo outras verdades, o que aumenta é o solo onde essas verdades se assentam e, da mesma maneira, o que recua é também o chão onde as outras verdades fincavam suas bandeiras. No campo das disputas científicas, o esforço não é o de hipertrofiar os enunciados, mas de ladrilhar o solo para que os enunciados possam circular. A abrangência de um idioma é do tamanho do número de bocas que o falam. Uma língua não “fica maior” porque agrega neologismos ou porque seus verbos ganham novas conjugações, mas sim porque mais diálogos são estabelecidos nela. Sem falantes não existe linguagem. No universo das verdades científicas o que se dá é o mesmo: deve-se criar o trilho por onde irá deslizar a sua verdade. O que deve crescer é o chão onde os enunciados pisam, e não a silhueta desses enunciados. Como se sabe, os homens não podem caminhar sobre as águas, mas conseguem andar em terra firme com maestria. Sendo assim, quando precisa atravessar um rio, ao invés de arriscar pisar na água, o homem constrói uma ponte para poder chegar ao outro lado. Seria um equívoco supor que, por cruzar pontes sobre rios, os homens podem andar sobre as águas. O que se fez foi criar chão no rio e não aprender a andar nele. Não se aumentou a variedade das superfícies sobre as quais podemos circular, o que ocorreu foi o aumento da área daquela única superfície em que andamos. Nós só sabemos andar na terra como sempre, a diferença é que, com a ponte, existe mais terra do que antes e agora temos mais espaço para nos deslocar. Caminhar sobre a água tornaria o humano mais poderoso, mas menos humano. Construir pontes não parece tão excitante, mas potencializa nossa natureza sem que precisemos abandoná-la. Além disso, andar sobre o 
rio é admitir que ele é um obstáculo incontornável, já erigir uma ponte para atravessá-lo é dominá-lo sem se trair. Esse ensaio quis ser um convite à construção de pontes: é bom que nós circulemos numa área cada vez maior, mas sem nunca esquecermos que é no nosso velho território que estamos pisando. Façamos com que nosso discurso se generalize sem que ele nunca abandone seu traço específico. Transformemos as coisas no nosso texto ao invés do nosso texto nas coisas. É necessário abandonar o ideal fáustico de se tornar um homem eterno, universal e desterritorializado que invade todos os territórios para que possamos nos enraizar em nosso território, não para nos encerrarmos dentro dele, mas para que ele se espraie. É importante que o pesquisador saiba o que é próprio à sua disciplina para que esse traço diferencial possa se desenvolver e ser amplamente reconhecido como tal. Eu sei que aqui as metáforas se confundem, já que quem consegue andar sobre as águas não é o demônio, mas sim seu rival, mas talvez o maior ardil do diabo seja justamente esse: fazer com que nos sintamos não como um de seus acólitos, mas como deuses.

Todo argumento que esboça uma tentativa de relativismo se vê na obrigação de encontrar um ponto arquimediano suspenso de onde possa tecer seus enunciados relativos de forma absoluta (ou denunciar as parcialidades de maneira imparcial), sem mergulhar no velho problema lógico da autorrefutação. Foi isso o que tentei rascunhar no parágrafo anterior: depois de tanto se criticar o desenraizamento e o universalismo satânico, não poderia eu deixar de pontuar "de onde" estou falando. Aqui também se quis construir um ponto arquimediano, só que ele não está “acima”, mas dentro: nesse ensaio o que se sugeriu foi um retorno à linguagem, não com o objetivo de se manter trancado em seu interior, mas para de lá de dentro de seus muros podermos lutar para que eles se afastem cada vez mais e nosso discurso se alastre. Como se falou: não se trata de saltar fronteiras, mas de alargá-las a partir de dentro. O lugar primordial de enunciação é, justamente, o interior do enunciado: o locus discursivo não antecede o discurso propriamente dito; eles não são sucessivos, mas simultâneos. "De onde" se fala e "o que se fala" são instâncias que se confundem: círculos concêntricos e não pontos apartados.

Em tempos em que tanto se questiona a utilidade das ciências sociais, talvez seja relevante nos perguntarmos antes o que significa ser útil para essa disciplina; às vezes o mais profícuo pode não passar da mais estéril representação, e aquele esforço 
tão pesado e por vezes autorreferente e encastelado pode conter a humildade do dever cumprido, posto que nunca se admite como terminado. Os que vendem sua alma para o demônio não percebem que aquela positivação que soava tão criadora era apenas um vazio espelhamento do nada, em contrapartida, o esforço autorreflexivo que parecia um autismo intelectual era, na verdade, a morada do potencial construtivista da sociologia. Por isso, convêm não reclamar muito do peso das inquietações sociológicas, caso contrário alguém pode lhe visitar a noite querendo fazer negócios.

\section{Referências Bibliográficas}

ADORNo, Theodor.; HORKHEIMER, Max. Dialética do Esclarecimento. Rio de Janeiro: Zahar, 2006 BAUMANN, Zygmunt. Legisladores e Intérpretes. Rio de Janeiro: Zahar, 2010.

BATESON, Gregory. NAVEN. São Pualo: Edusp, 2008.

BORGES, Jorge Luis. Outras inquisições. São Paulo: Companhia das Letras, 2007. BOURDIEU, Pierre. Coisas Ditas. São Paulo: Brasiliense, 1990.

DELEUZE, Gilles. GUATTARI, Felix. O Anti-Édipo: capitalismo e esquizofrenia I. São Paulo: 34, 2010. Foucault, Michel. As Palavras e as Coisas. São Paulo: Martins Fontes, 2007.

KuHN, Thomas. A Estrutura das Revoluções Científicas. São Paulo: Perspectiva, 2011.

MANNHEIM, Karl. Ideologia e Utopia. Rio de Janeiro: Zahar, 1972.

MARX, Karl. O Capital. São Paulo: Civilização Brasileira, 2008.

orTIz, Renato. A Diversidade dos Sotaques: o inglês e as ciências sociais. São Paulo: Brasiliense, 2008.

VIVEIROS DE CASTRo, Eduardo. O Nativo Re-

lativo. Mana. V. 8 N.1 p. 113 - 148, Abril.

2002. Quadrimestral. Disponível em: http:// 
www.scielo.br/scielo.php?pid=So104-

-9313200200010ooo5\&script=sci_arttext. Acesso em 29/o6/2012.

. A Imanência do Inimigo. In: A Incons-

tância da Alma Selvagem. São Paulo: Cosac\&Naify,

2011.

WAGNER, Roy. A invenção da Cultura. São Paulo:

Cosac\&Naify, 2010. 